\title{
Recensão.
}

\section{Uma leitura crítica do livro "Esses Ossos" editado pela In-Libris}

\section{José Eduardo Reis}

Universidade Trás-os-Montes e Alto Douro

As 39 imagens fotográficas de estruturas ósseas de animais não humanos e os 36 poemas de bichos e ossos de 22 poetas portugueses que configuram o livro compósito Esses Ossos podiam servir de ilustração contemporânea a um pastiche do famoso aforismo do poeta lírico grego dos séculos VI e V a. C., Simóndes de Céos, citado por Plutarco: "a fotografia é poesia muda e a poesia é fotografia falante". A correlação estabelecida por Simónides é obviamente entre a poesia e a pintura. Mas, dado ser a fotografia uma forma de arte predominantemente mimética, será abusivo ver nela - enquanto 'obra de arte na era da sua reprodutibilidade técnica', para utilizarmos o título de um famoso ensaio de Walter Benjamim - uma sucedânea da pintura, de modo a assegurar a analogia proposta por Simónides entre a sua qualidade figurativa e a qualidade imagética da palavra poética? Como todas as analogias que se querem intelectualmente produtivas, esta não tem em vista homogeneizar, assimilar, reduzir, anular, mas antes aproximar, convocar, reunir, justapor dimensões discretas do conhecimento, neste caso estético, do mundo. Só parcialmente, porém, Simónides pode ser convocado para servir de auxiliar de leitura ao livro Esses 
$\underline{\text { Ossos, }}$ porquanto este se apresenta como uma obra multidisciplinar, aberta sobre uma "paisagem sonora" - a que se acede pelo desenho da contracapa, um código de leitura óptica (QR code) - e como uma componente estética de um projecto de investigação arqueogenética sobre bovinos ibéricos. 0 livro a que aqui nos reportamos é portanto um objecto situado entre arte e a ciência, mas também uma peça constituinte de uma instalação artística para a qual contribuíram, sob a curadoria de Catarina Ginja, as fotografias de Paulo Gaspar Ferreira, os poemas selecionados por Isaque Ferreira e a composição sonora de Brendan Hemsworth.

Prosseguindo na arqueologia das conjugações estéticas intersemióticas inaugurada por Simónides e continuada pelo dito famoso de Horácio ut pictura poesis - "como a pintura é a poesia" -, chamemos à colação, como outra possível filiação do projecto de composição interartístico de Esses Ossos, o modelo renascentista e barroco do emblema instituído pelo humanista italiano Andrea Alciato.

\section{On the four seasons of the year}

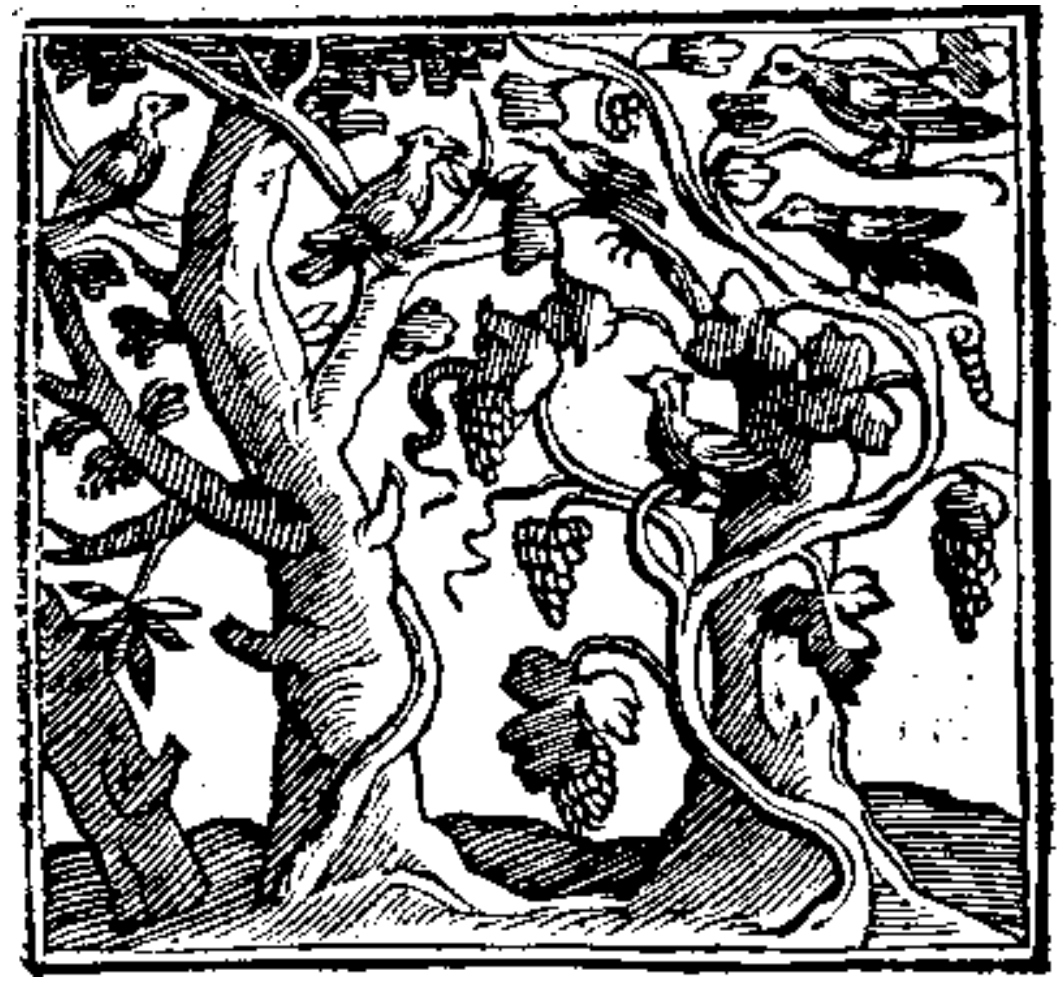


The winged robin declares that winter has arrived. The twittering swallow returns to us in early spring. The cuckoo announces that he himself expects the summer. Figpeckers are seen only in the autumn

Peace

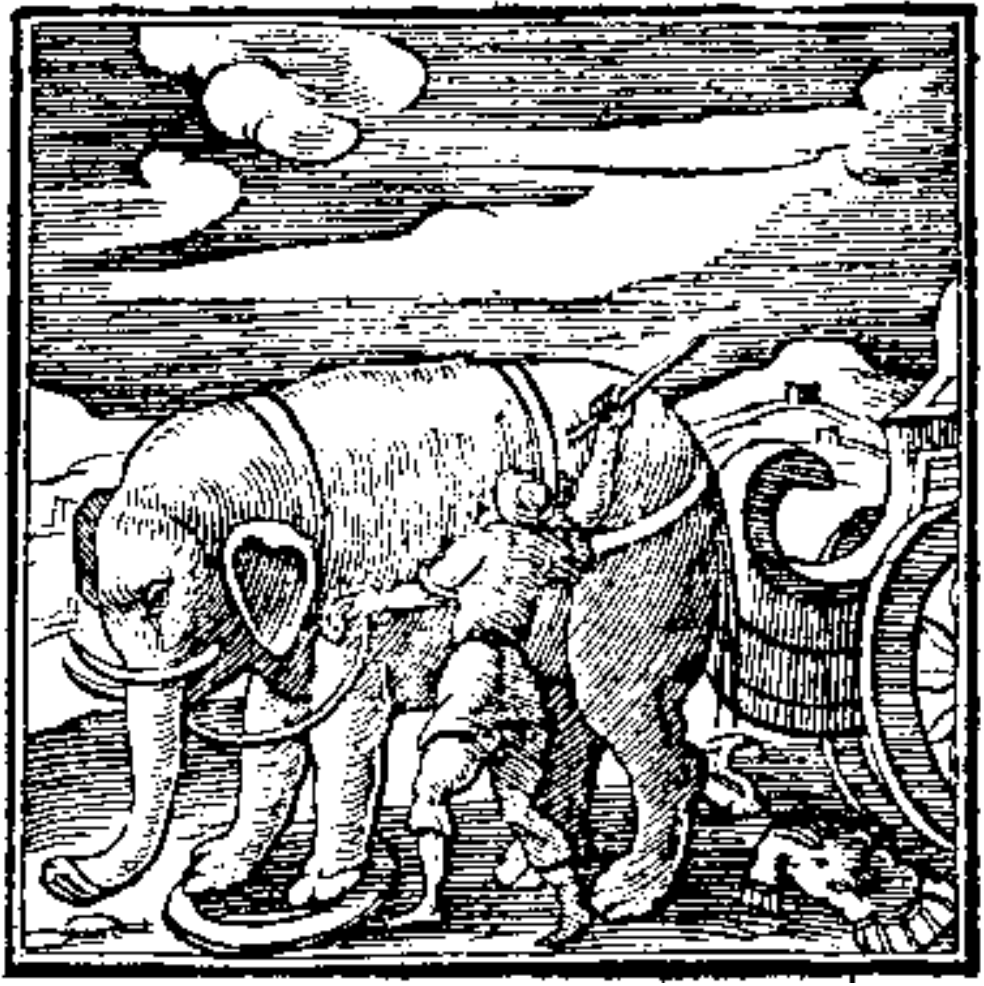

The elephant, with his tower-bearing shoulders, and ivory tusks, though accustomed to ferocious domination in martial conflict, has placed his neck under a yoke, and driven by goads, he pulls the chariots of Caesar to sacred temples. Even a wild beast recognizes nations everywhere in harmony and, when arms are laid down, he discharges the offices of peace.

No seu Emblematum libellus (1531) coexistem vários tipos de texto: o visual, representado por uma gravura, e o verbal, constituído quer por um mote ou lema, a inscriptio, que encima a imagem e condensa o seu significado simbólico, quer por um epigrama, a suscriptio, que, à maneira de uma legenda, tem por função comentar a lição moral e didática da figura. Para além da associação da palavra poética à imagem fotográfica evocadora da lógica composicional do antigo emblema, foi consultando os dois índices de 
Esses Ossos que vimos reforçada a sua possível filiação naquela antiga subespécie literária: enquanto o índice dos poemas identifica as suas respectivas autorias, os livros da sua proveniência e as datas das suas edições, o índice das fotografias fornece informação detalhada sobre a morfologia dos ossos, nomeando, sucessivamente, a sua forma, a sua nomenclatura científica latina, a sua designação vernacular, o lugar do seu achado, a sua datação, a sua inventariação e localização museológica - (e.g. da fotografia indexada da p. 21: Crânio, Canis Lupus Familiaris, Cão Doméstico, Cabeça da Arruda, Concheiros de Muge, Mesolítico, Museu Geológico). Se a variada justaposição gráfica da poesia muda da fotografia com a fotografia falante da poesia de Esses Ossos não tem como evidente propósito seguir o programa sentencioso do livro de Andrea Alciato, isso não anula a possibilidade de nela se discernir, a par de uma intenção estética, uma intenção ética - afim do didatismo do emblema - neste caso pela condição animal não humana. Mas nas suas setenta páginas, em que se articulam imagens de estruturas ósseas de bichos domésticos e selvagens com estruturas textuais moduladas sob a forma de versos, pode-se também discernir o elo comum da autopoesis dos sistemas de vida da matéria e do espírito. E ainda a presença de duas arqueologias, a que busca as origens da morfologia animal gerada pela mão da natureza e a que dá voz à genesíaca palavra literária inventada pela faculdade de representação humana. Não se nota porém a intenção ecfrástica do poema servir de ilustração à fotografia, nem da fotografia servir de suporte ao conteúdo do poema. 0 trabalho de composição não consistiu em traduzir significados de e para linguagens diferentes mas em gerar sentidos abertos a partir da intersecção dessas diferenças de linguagens. E o efeito é sinestésico, isto é, múltiplo nas suas possibilidades de apreensão sensorial e intelectual.

Há páginas em que a mancha gráfica do texto contrasta com a forma do osso contiguamente representado. Isso sucede, por exemplo, com a formatação vertical e paralelística do poema “Obra de Arte” (p.28), de João Habitualmente, em contraponto com a imagem de um círculo vazio perfeito num fragmento occipital de um crânio de bovino (p.29). 


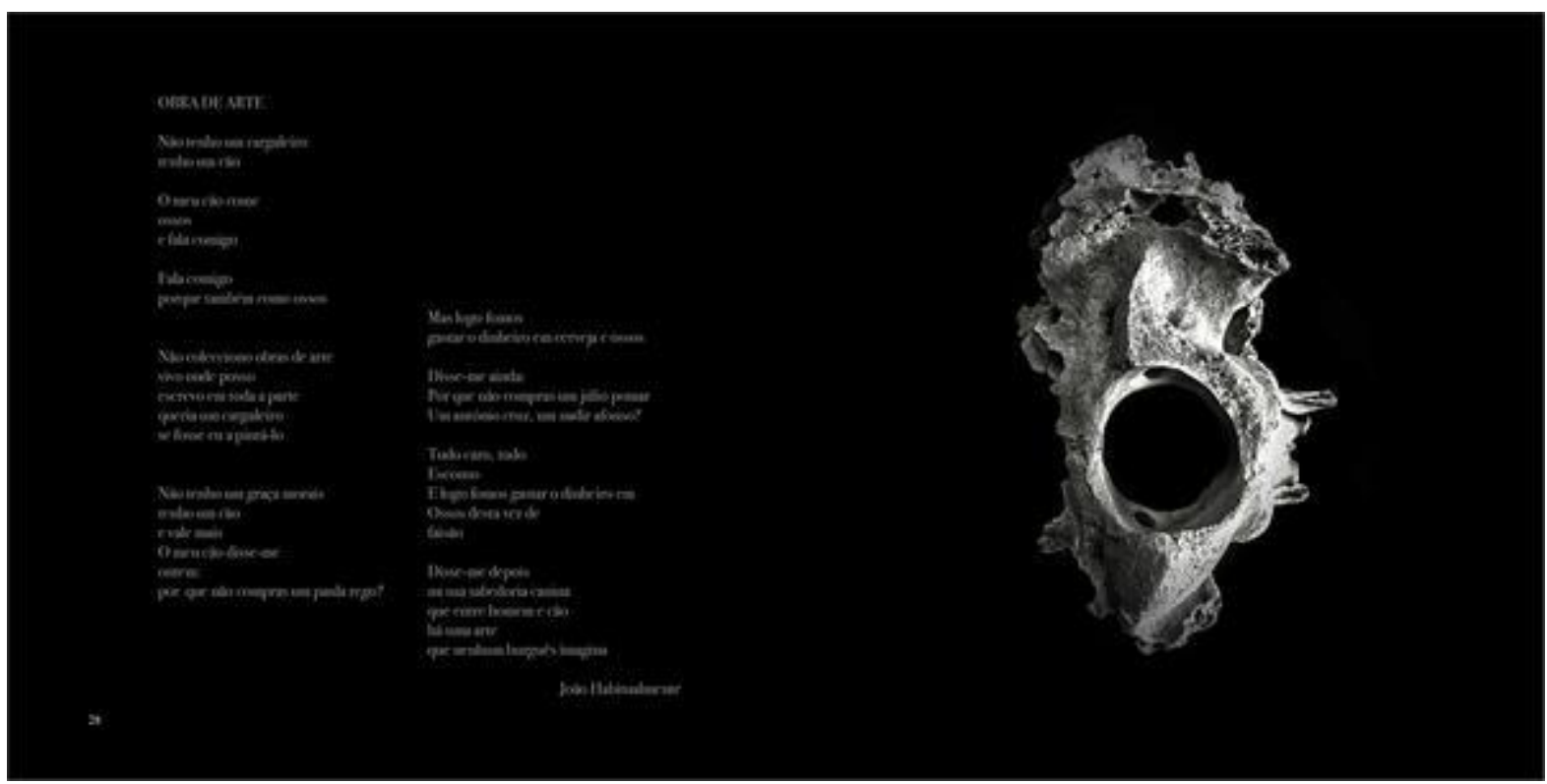

Outras em que essa disposição vertical do texto é simetricamente especular da fotografia impressa, como sucede com a sequência de páginas que exibem o poema de Sofia de Mello Breyner "As pessoas sensíveis" (p.34) e o Cúbito do Bos Taurus achado em Leceia (p. 35).

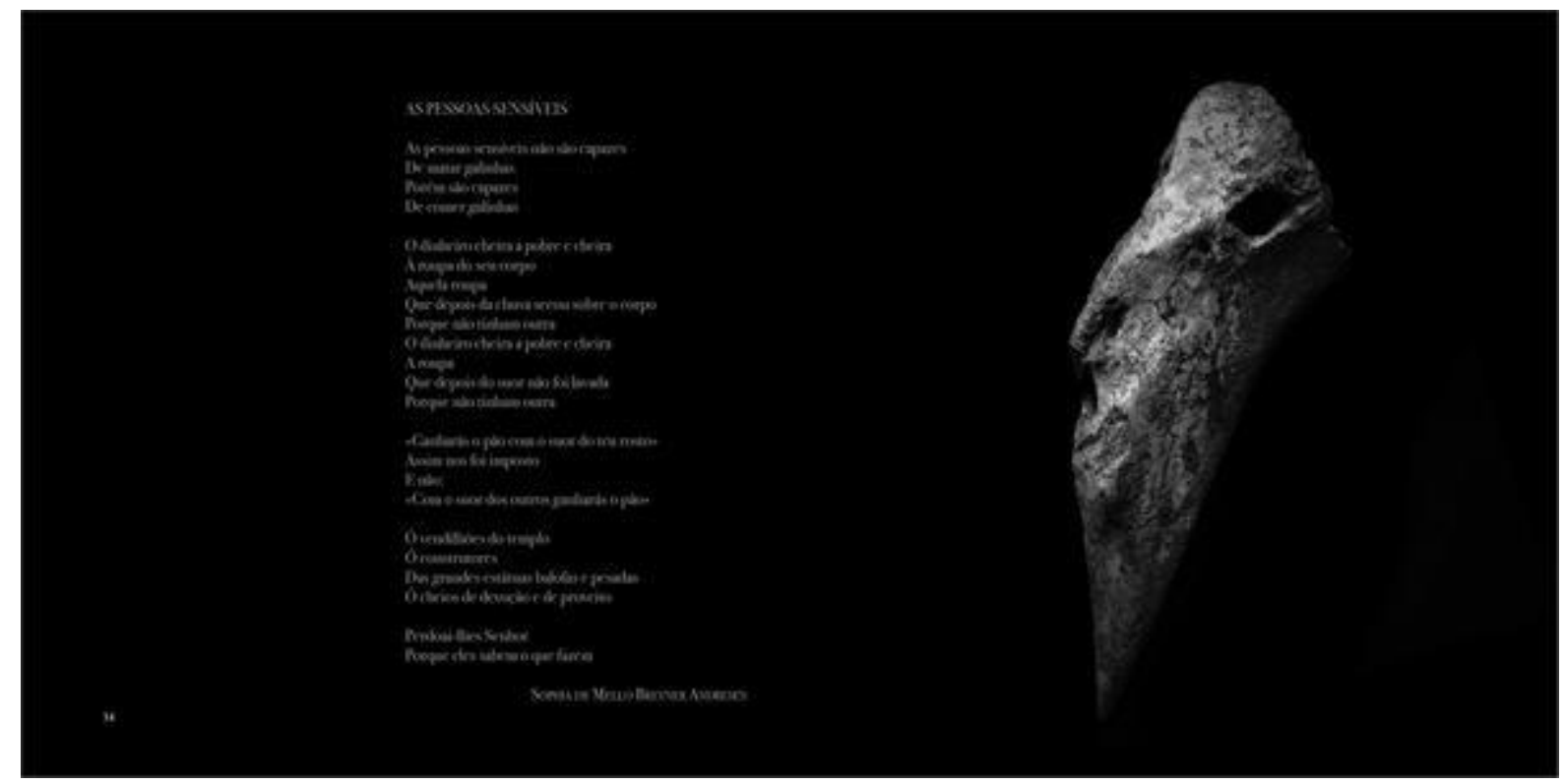


Outras ainda em que o texto surge quase como uma extensão ou emanação da imagem, como no poema "O animal abria-se à ternura/ que, devagar, se dava à inteligência" (p.58), de Fernando Echevarria, inserido na concavidade da mandíbula de um Lobo Ibérico (p.58-59).

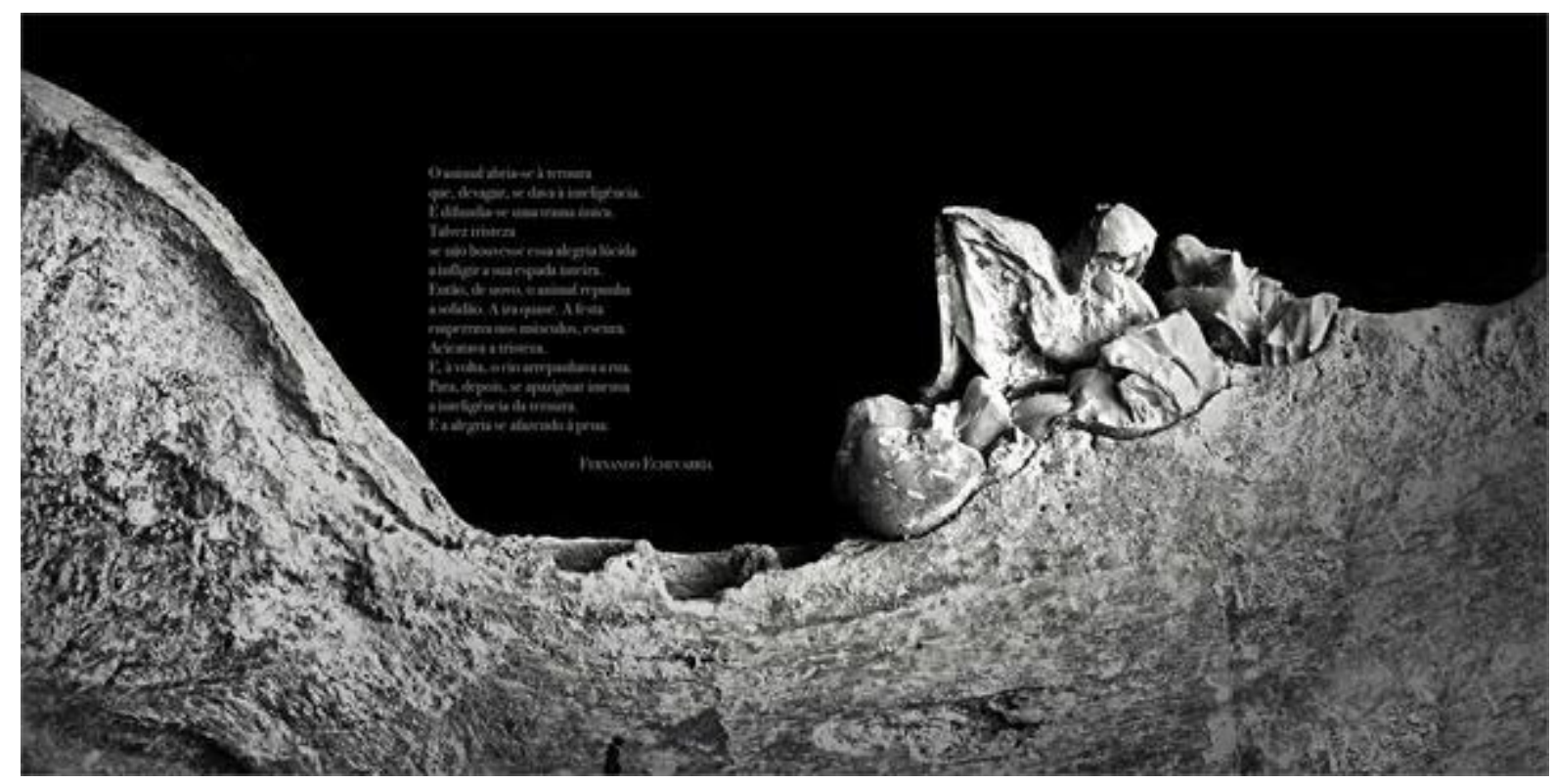

Dir-se-ia que a haver uma intenção ilustrativa ela não se processa tanto por correspondências pré-estabelecidas mas por justaposições descontínuas entre poemas e imagens, não tanto pela harmonização de significados mas pela sugestão combinada de significantes textuais e icónicos. É assim que as delgadas costelas de Mamífero, descobertas em São Miguel de Odrinhas (p. 27), nada têm morfologicamente a ver com o sentido do poema de Beatriz Hierro Lopes - "Os ossos dos pássaros mortos como relíquias de santos; usá-lo-ia a todos se com / isso achasse atrair boa sorte" - (p.26), embora a fotografia da sobreposta disposição oval dos ossos pareça servir-lhe de referente visual. 


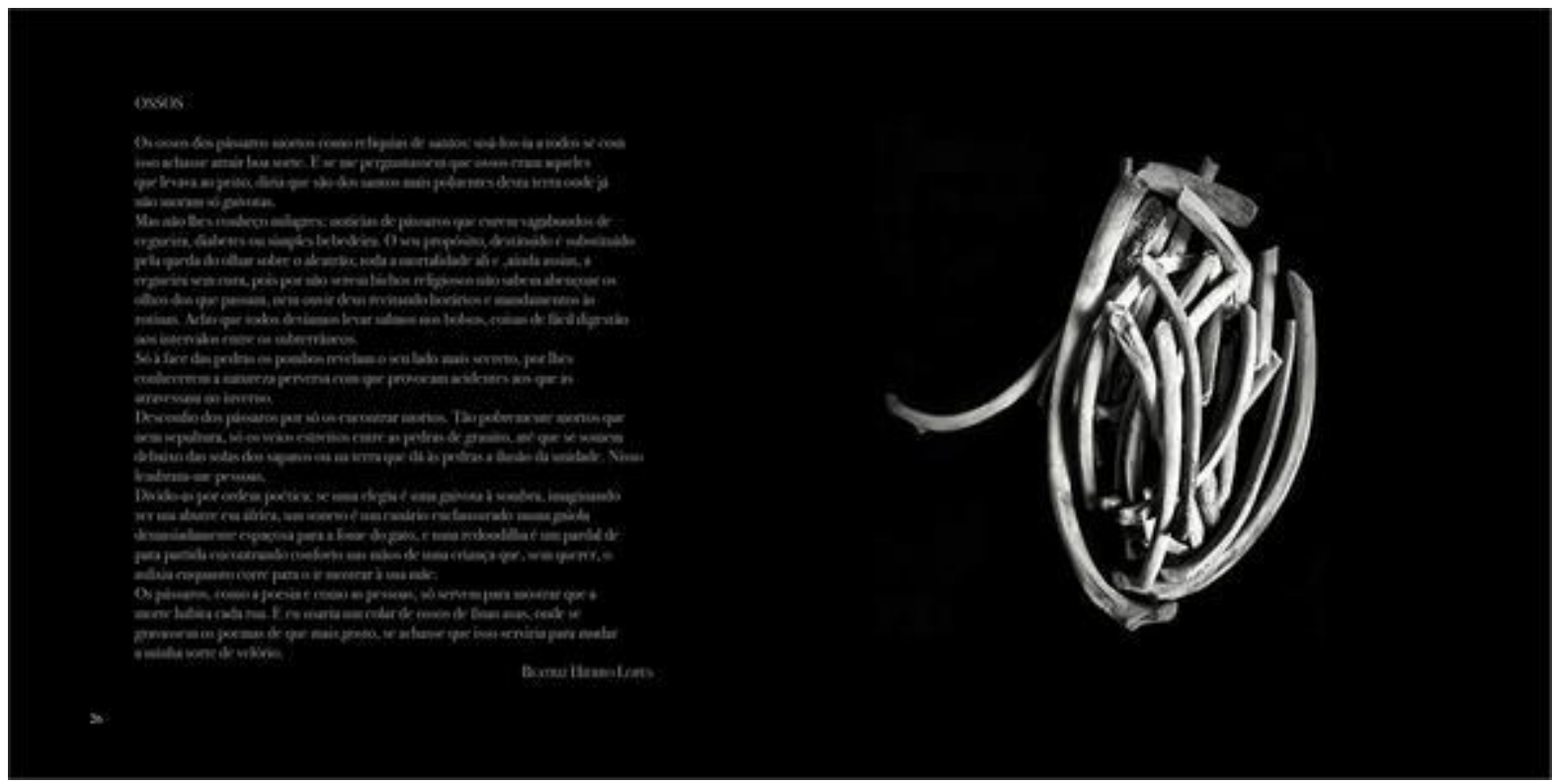

São portanto quase raras as aproximações do significado animal a que alude o texto à imagem óssea que o representa. E, quando ocorrem, não visam a univocidade da ilustração.

Leia-se o poema "Coelho" (p.64), de António Osório - “Coelho velho e de casa, / vindo ao colo, limpo e livre. / Da morte salvou-o um rapaz, / no mesmo quarto dormem, / dois animais compassivos: / rapaz com intimidade de coelho, / bicho com encanto de rapaz" -

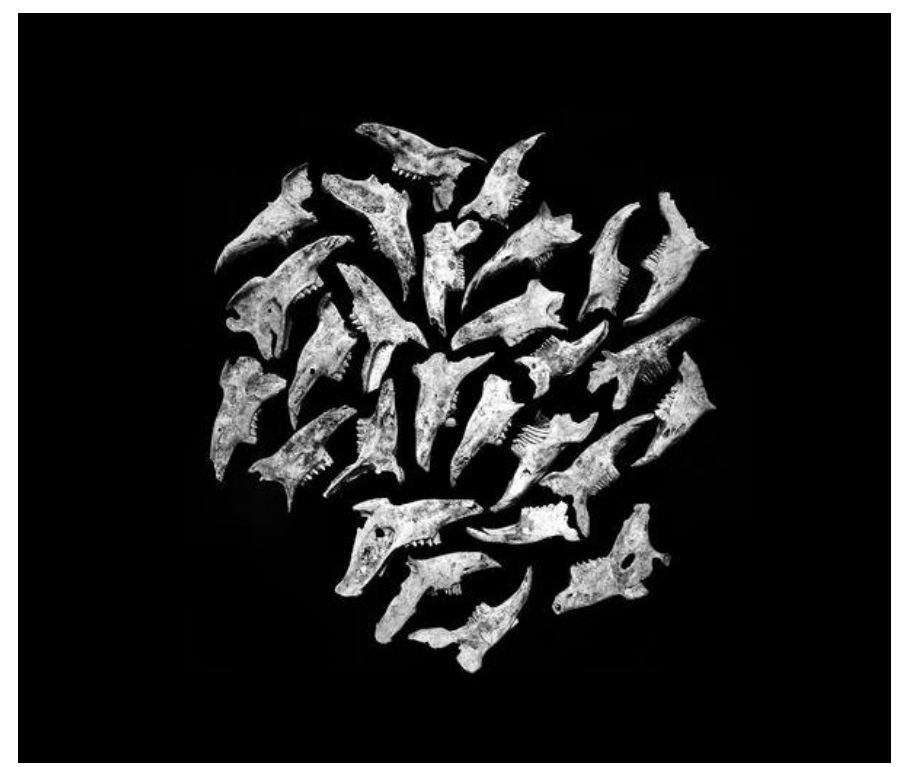


e veja-se a dinâmica e rotativa composição das "Mandíbulas de Coelho Bravo Europeu" (65) descobertas no Cabeço da Arruda, Concheiros de Muge: à imagem verbal de um singular coelho doméstico, humanizado, serve de contraponto a imagem fotográfica de uma pluralidade de mandíbulas de coelhos bravos, como que se nessa justaposição de sentidos opostos a partir de um denominador de sentido comum (o coelho) se procurasse sugerir uma leitura estética enriquecida pelo contraste e não limitada à informação de uma legenda denotativa.

Consultemos ainda de novo os índices e vejamos três títulos de poemas em correspondência com os índices das imagens que se lhes justapõem para assinalarmos outras sugestivas continuidades ao nível do significado. Em “Procissão dos animais” (32), de Rui Lage, o número plural é o nexo legível e visível entre duas gramáticas, a do texto, evocador de uma espécie de festa pagã - "Deu consigo na procissão dos animais / a contemplar burros galantes / mulas toucadas de grinaldas, / malmequeres nos alforges / rosas nas albardas" - e a fotografia que representa a anatomia de falanges de cavalo doméstico, postas a descoberto na Lapa da Bugalheira, Torres Novas.

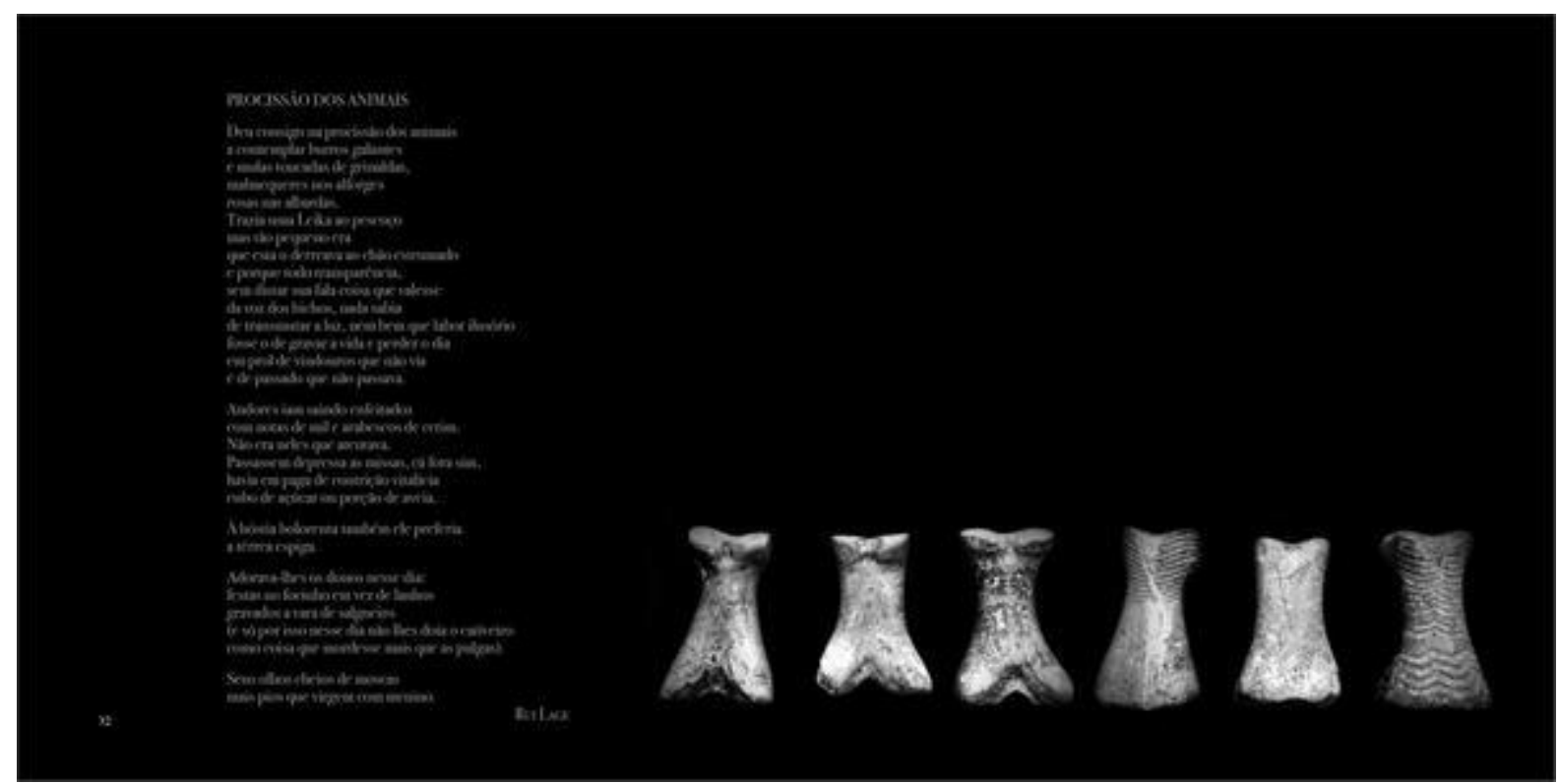


No poema “Lego” (p.82), de Alexandre O’Neil, que fala da artificialização da natureza e da vida animal - "Está tudo conformado / ao triste proprietário. / Mecânicas ovelhas, / na erva de plástico, / têm pastor de pilhas / e cão pré-fabricado // A malhada, no estábulo, / quase manga de Alpaca / (é A VACA, sabias?)" - associa-se ao “Chifre” (83) de um Bovídeo doméstico descoberto em São Miguel de Odrinhas. Aqui o título para um poema irónico é ilustrado por um osso pontiagudo fraturado, mas passível de ser (quase) religado como peças de Lego.

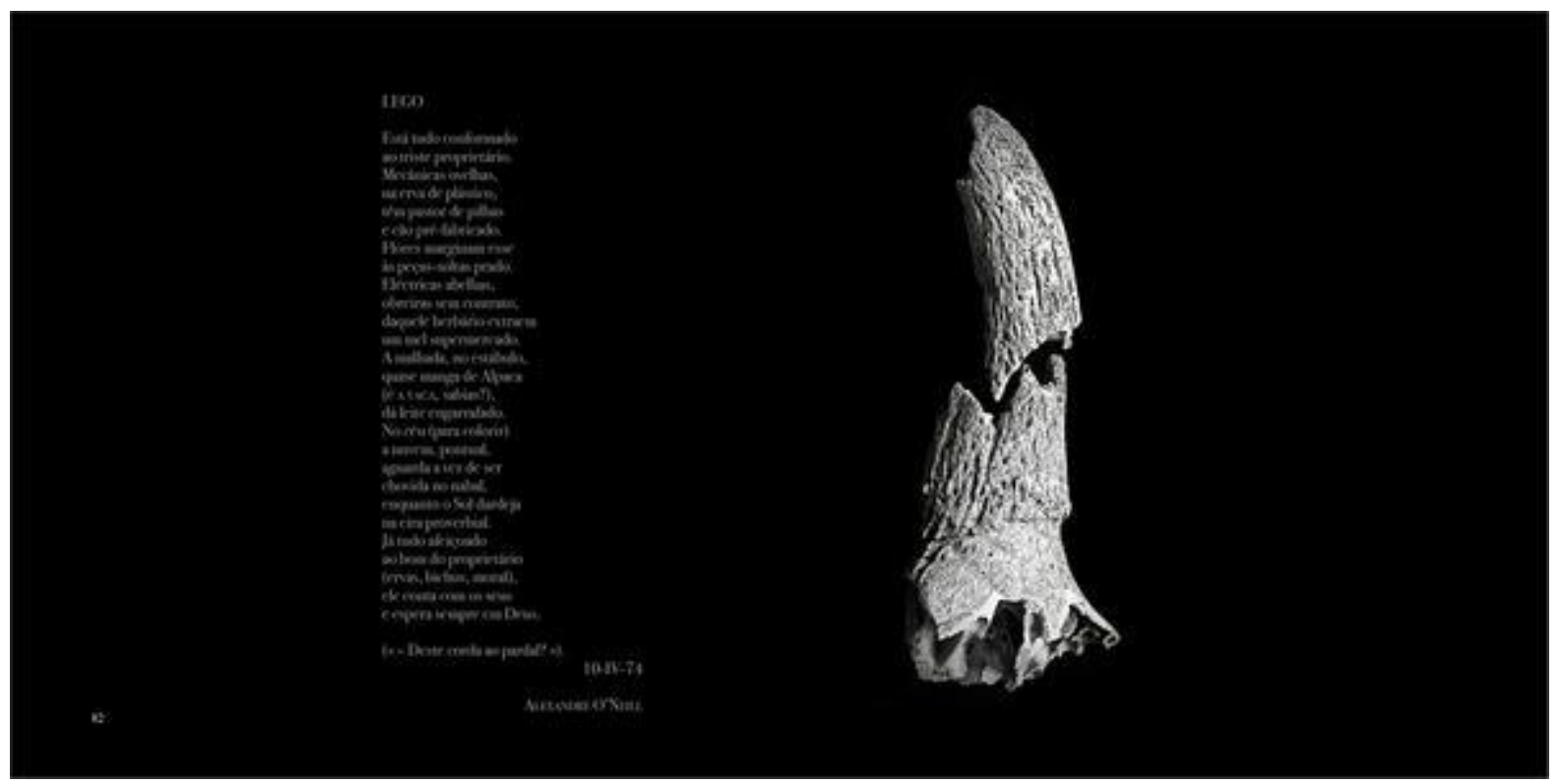

Já a imagem de um úmero de uma cabra selvagem, disposta como uma bissetriz em relação à mancha gráfica do texto, amplia o sentido do título do poema de Daniel Jonas, "Anho de Deus" (p.53), evocador da Paixão de Cristo, na intercessão simbólica que sugere do auto coercivo e silencioso sofrimento anímico com o sofrimento físico de um cabrito sacrificado para servir de alimento: "A dor tende ao silêncio: para quê / contar a tortura / se ela mesma nos venda a língua / para a paz? // Assim com este cabrito: torturado / e silenciosamente / servido na paz muda deste almoço / de família." 


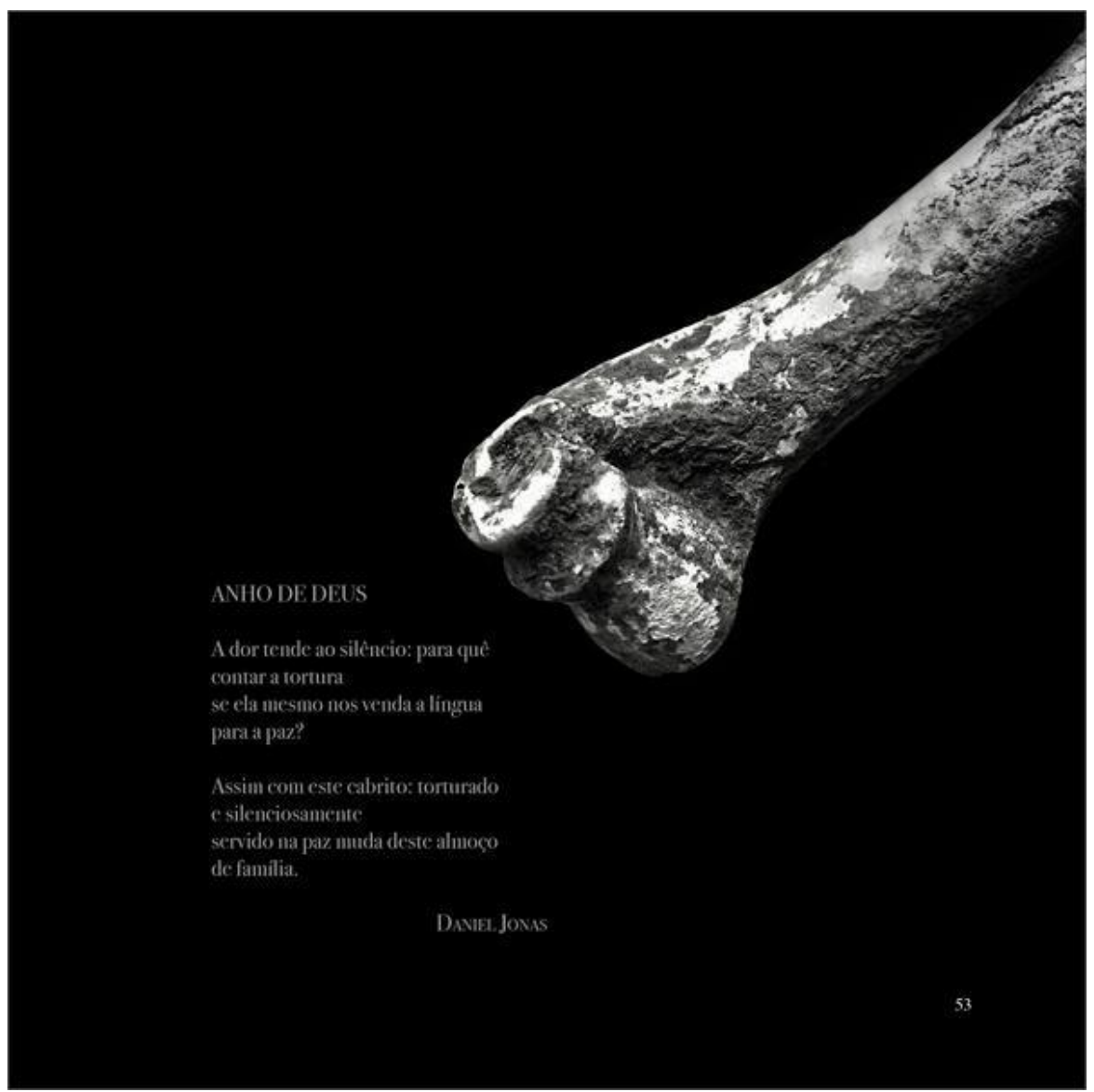

Quer se atenda a interpretações que assinalem descontinuidades inter semióticas ao nível do significante, quer se dê realce às que sugerem convergências ao nível do significado, os atos de leitura que este livro propõe a partir de poemas contemporâneos sobre animais vários são sempre duplicados pelas fotografias sobre ossos antiquíssimos de animais que os acompanham, embora, reversivelmente, também se possa dizer que é a partir de fotografias sobre ossos antiquíssimos que se chega a leitura daqueles poemas contemporâneos.

Na diversificada e inventiva articulação da palavra poética com a fotografia estética, a composição gráfica de Esses Ossos inaugura assim possibilidades de leituras múltiplas que variam em função do efeito de estranhamento-deslumbramento que provocam. E para esse duplo efeito concorrem três ordens de valores fundados em oposições diferenciais: entre o negro do fundo da paginação e o branco luminoso das letras dos poemas e do cinzento 
sombreado das fotografias; entre a contemporaneidade dos textos e a antiguidade das formas ósseas fotografadas a partir de escavações arqueológicas feitas no século XIX e XX e preservadas no Museu Geológico, no Laboratório de Arqueociências e no Museu Arqueológico de São Miguel de Odrinhas; entre a nomenclatura dos animais comuns convocados para os poemas e a dos animais arcaicos metonimicamente representados por aquelas formas ósseas. É assim que as letras brancas dos versos de poemas sobre animais comuns enunciados pelo número gramatical do plural - burros (1), mulas (1), gansos (1), patos (1), pintos (1), galgos (1) - ou segundo um número variado de ocorrências - pombo (1), peixe (1), rato (1), coelho (1), cabrito (1), vacas (2), gatos (2), bois (3), cavalos (3), galinhas (4), cães (4) têm por contraponto um número diversificado de imagens de animais selvagens - auroques (7), cavalos (3), coelhos, (3), lobos (2), javalis (2), cabra (1) - e seus sucedâneos domesticados - cães (6), bovinos (5), ovelhas (2).

Essas oposições diferenciais são aliás prefiguradas pela dissemelhante concepção da capa

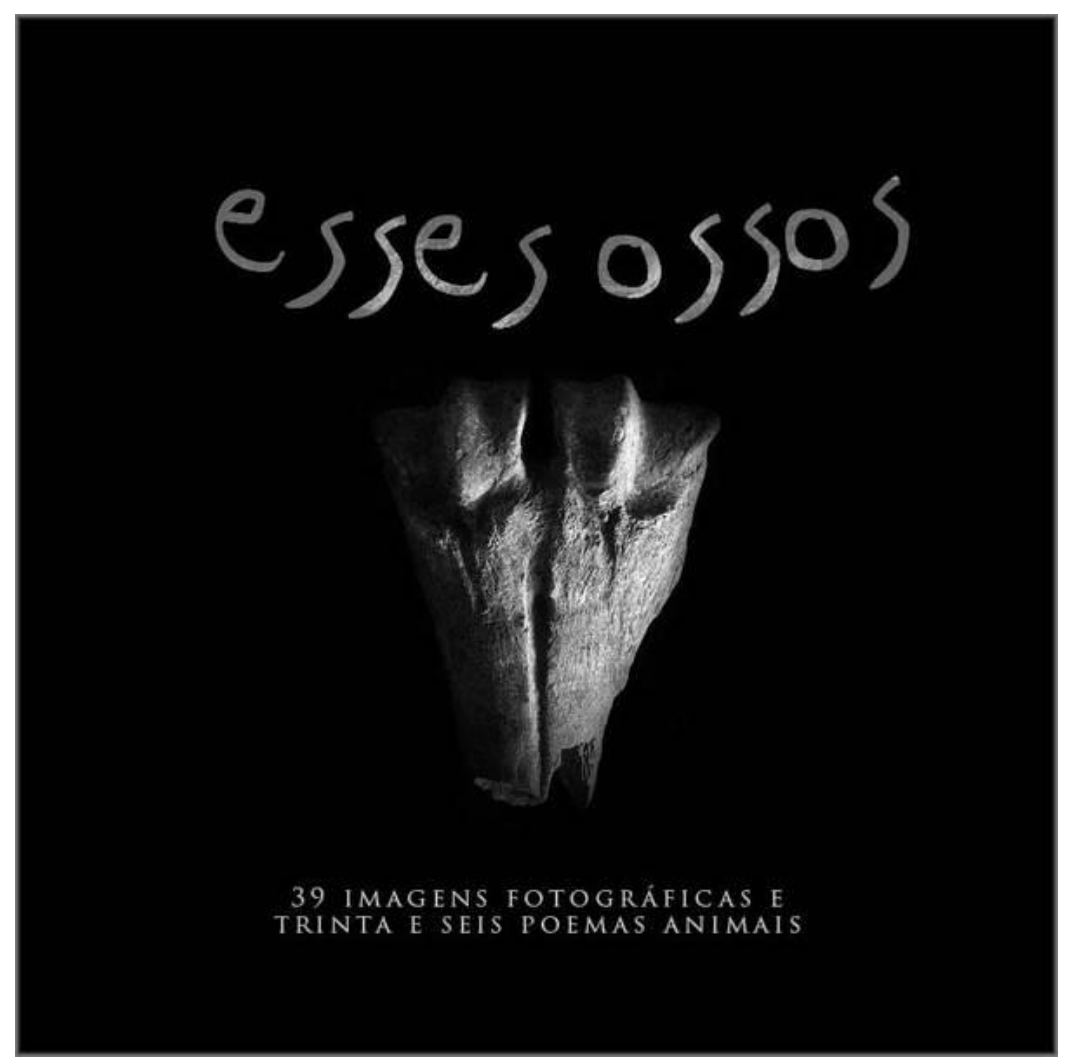


- remetendo para o passado dos achados arqueológicos - e da contracapa - orientado para o futuro da comunicação digital: aquela, sugerindo pelo grafismo do título e pelo vestígio arqueológico nela fotograficamente representado - um metacarpo de um auroque -, a matéria arcaica de parte do conteúdo do livro; a segunda, cumprindo a sua funcionalidade de código de hiperligação, exibindo um padrão de linhas geométricas moderno.

A sequência alternada, por vezes justaposta, de texto e imagem de Esses Ossos constrói-se, portanto, a partir deste improvável convívio de morfologias e de camadas de tempo discretos, reunidos e cerzidos sob o influxo de modos poéticos, científicos e técnicos de representação e conhecimento do mundo. 0 engenho manifesta-se na abundante variedade das construções líricas selecionadas e das funções ósseas retratadas, mas também na subliminar consciência ética de respeito pela condição animal que se comunica ao longo do livro. Vejam-se o poema de abertura “O Novíssimo Testamento “(14) de Jorge Sousa Braga, mas também o poema final, "Um dia" (84), de Sophia de Mello Breyner Andresen. No primeiro texto - distribuído simetricamente por duas páginas ocupadas ao centro pela imagem fotográfica de um fragmento de um maxilar de bovino doméstico, animal híper sacrificado pelos hábitos alimentares do homo sapiens - lê-se: "Este é um testamento escrito com o sangue / do último dos genocídios - e esse sangue é da cor do alcatrão - / tendo como testemunhas apenas as duas metades / do meu coração."

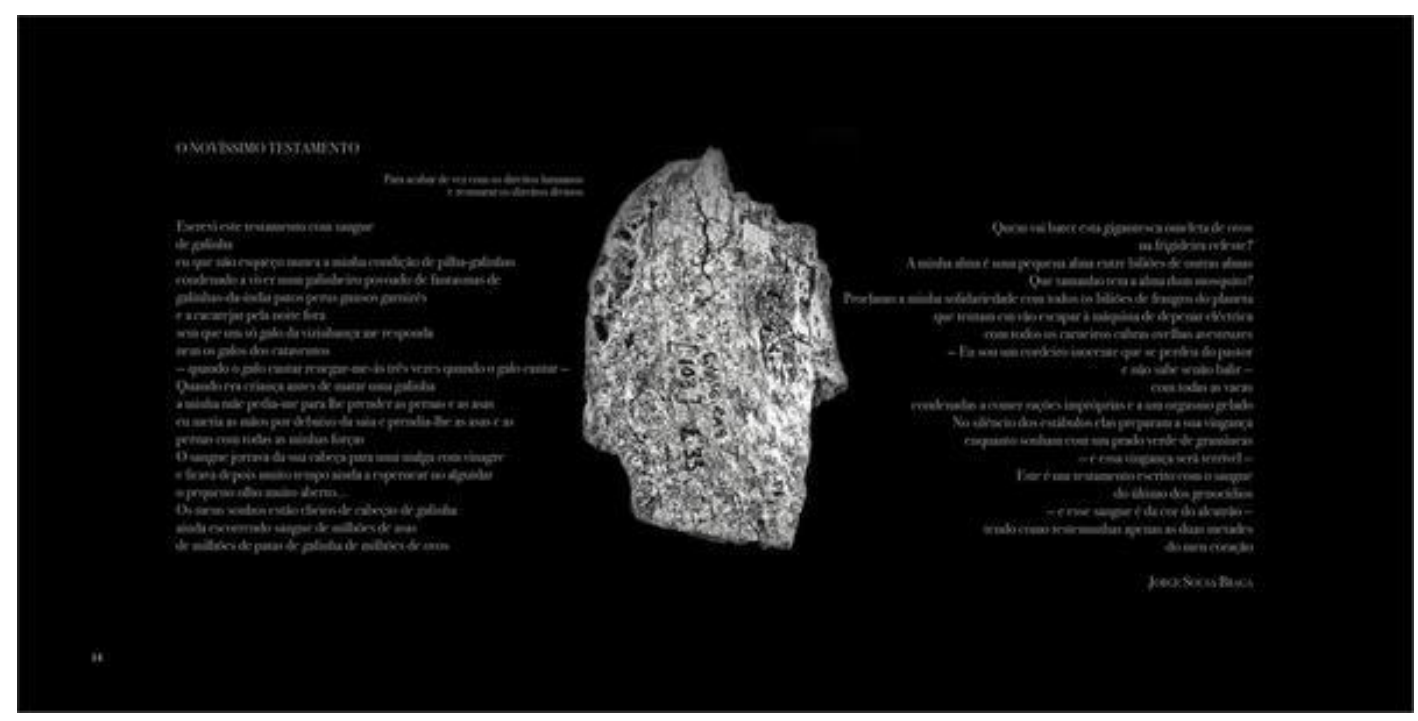


No último, acompanhado pela mesma imagem (85) do metacarpo de um auroque representada na capa, deixa-se em aberto a ideia ou esperança utópica da reconciliação dos viventes humanos e não humanos, já veiculada por Isaías 11, de uma metanoia universal futura: “Um dia, mortos, gastos, voltaremos / A viver livres como os animais / E mesmo tão cansados floriremos / Irmãos vivos do mar e dos pinhais // 0 vento levará os mil cansaços / Dos gestos agitados, irreais / E há-de voltar aos nossos membros lassos / a leve rapidez dos animais // Só então poderemos caminhar / Através do mistério que se embala / No verde dos pinhais, na voz do mar / E em nós germinará a sua fala".

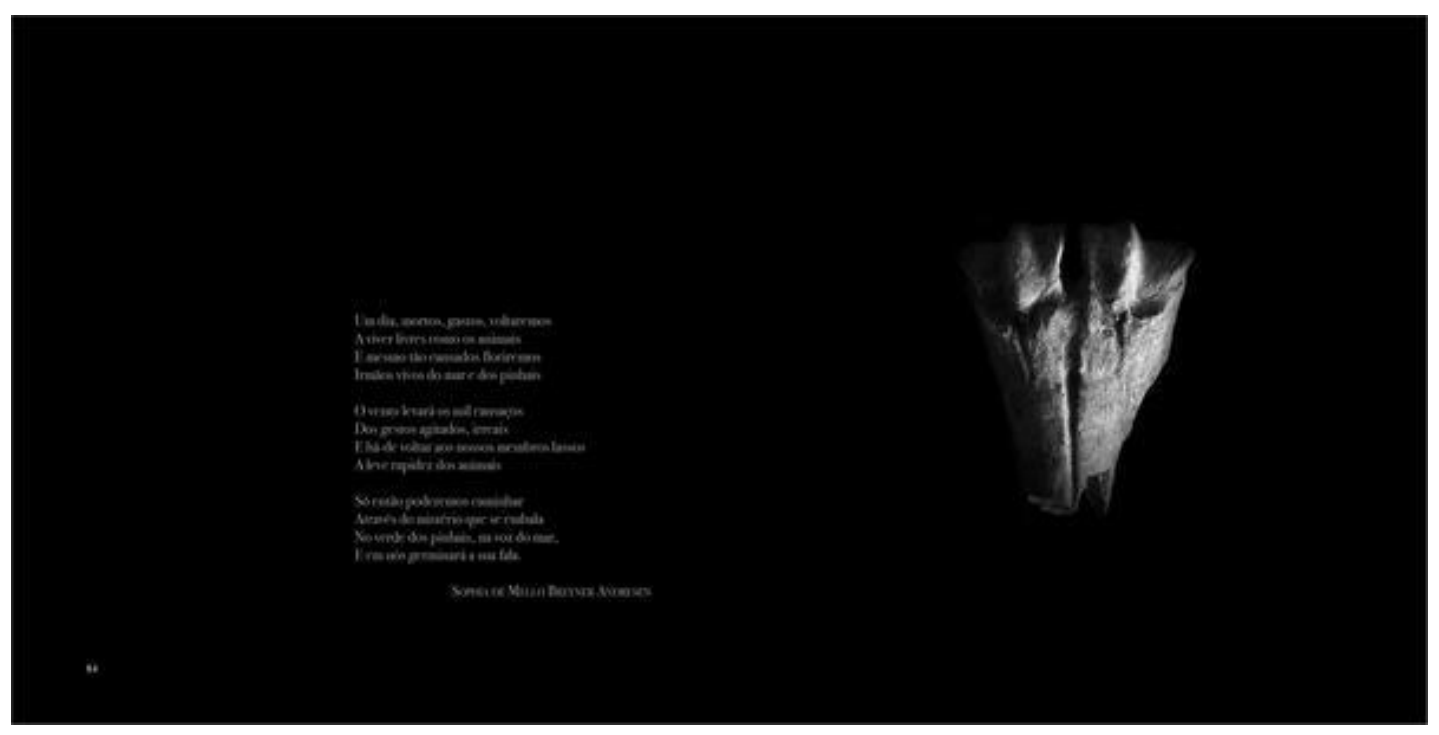

Na sua esplêndida beleza e inteligente evocação poética das origens zoomórficas, Estes Ossos é um livro-projecto que nos coloca no centro de muitas questões, antigas e contemporâneas, incluindo a questão metafísica de se saber se no princípio do princípio era o verbo ou se no princípio do princípio era o osso. Questão indecidível, para a qual só podem continuar a ser escritas e geradas novas e infinitas hiperligações no livro aberto da natureza. 